\title{
HIPÓCRATES X HIPOCRITÉS: O DESTINO DA EDUCAÇÃO DECIDIDO EM UMA LETRA?
}

\author{
Vinicius Bertoncini Vicenzi*
}

\begin{abstract}
RESUMO
Este artigo pretende apresentar uma discussão entre dois caminhos paradigmáticos aos quais a pedagogia parece se submeter historicamente. O primeiro deles, o caminho de Hipócrates, numa destinação médicocientífica. O segundo, o de Hipocrités, numa destinação artístico-retórica. Não se espera, nessa breve discussão, contudo, uma definição a respeito de uma possível tomada de decisão, voluntarista, acerca dessas destinações. Não se trata, também, de um mero jogo de palavras. A intenção aqui é buscar, no referencial da filosofia antiga e da etimologia dos vocábulos gregos, duas maneiras de ver o processo de relação dos saberes com a verdade, relação esta que produz uma série de impactos sobre a maneira como enxergamos o processo educativo.
\end{abstract}

Palavras-chave: Destino da educação. Filosofia da educação. Hipócrates. Hypokrités. Retórica.

\begin{abstract}
This article aims to present a debate between two paradigmatic paths through which pedagogy seems historically to submit itself. The first of them, Hippocrates' path, in a scientific-medical destination. The second, Hipocrites' path, in a rhetorical-artistic destination. It is not expected here, in this brief exposition, any definition between a decision-making, willfull, about these destinations. It is not, also, a mere wordplay. The intention here is to search, in ancient philosophy's references and in Greek vocabularies' etimology, two ways of seeing the process between
\end{abstract}

\footnotetext{
* Mestre em Educação pela Universidade do Estado do Rio de Janeiro. Doutorando em Filosofia pela Universidade do Porto/Portugal. Bolsista da CAPES - Proc. $n^{0}$ 10795/138. Membro fundador da Sociedade Brasileira de Retórica (SBR). Membro do grupo de pesquisa "Aesthetics, Politics and Art Research Group" do Instituto de Filosofia da Universidade do Porto.E-mail: viniciusvicenzi@gmail.com
} 
the relation of knowledges and truth, relation which produces a series of impacts over the way we understand educational process.

Keywords: Education's destiny. Philosophy of education. Hippocrates. Hypokrités. Rhetoric.

\section{Hipócrates: o destino-médico}

Aproximemo-nos do que chamamos de destino da pedagogia. A que a pedagogia está destinada? Ou a que se destina, a que se envia? $\mathrm{O}$ que quer a pedagogia? Aludimos a dois lugares, ou melhor, a dois personagens: Hipócrates, o médico; e Hipocrités, o ator. Uma letra, $a$ ou $i$, decidindo o futuro de nós, professores. E o que significa essa letra? Antes de uma consideração filosófica desses dois personagens, vale a pena a atenção à palavra ${ }^{1}$. Hipócrates, antes de significar o famoso médico, "pai" da medicina ocidental, significa hipo-crates, ou seja, uma palavra grega formada por dois radicais, hypó, prefixo que significa "abaixo", daí "hipotermia", "hipotálamo", etc., e por krátes, derivado do verbo grego kratéo que significa "ser forte", "ser poderoso", com o sentido de "governar sobre", "conquistar". O substantivo correlato a esse verbo é krátos, que significa "força”, "poder", "regra", "soberania", "vitória", cuja raiz é krás, que significa simplesmente "cabeça", ou seja, krátos traz consigo o sentido de "poder", de "regra", como organização, como regulação "racional". Assim, no aspecto etimológico, ao falarmos de uma pedagogia hipocrática, estamos falando em uma pedagogia baseada num poder, em regras racionais, em uma certa governabilidade dada desde um plano inferior, um plano humano. Já Hipocrités, antes de significar especificamente o ator, também é composta por hypó, ou seja, "abaixo", mas também por krités, cuja raiz é o verbo kríno, "separar", "escolher", "decidir", "julgar", "questionar", de onde se formará também a importante

\footnotetext{
As considerações etimológicas aqui feitas provêm da plataforma online Perseus Digital Library <www.perseus.tufts.edu/hopper> e do seu respectivo dicionário: LIDDELL, Henry George; SCOTT, Robert. A Greek-English Lexicon. Oxford: Clarendon Press, 1940. Disponível em: <www.perseus.tufts.edu/hopper/text?doc=Perseus:text:1999.04.0057>. Acesso em: 24 jan. 2013. Manteremos, para efeito de discurso, as aliterações para o português, substituindo o "k" e "y" gregos pelos nossos "c" e "i" respectivamente.
} 
palavra krísis, cujo sentido originário de separação e julgamento está ligado a um evento, a algo importante de ser decidido, como uma guerra, por exemplo. Hipocrités, assim, antes de ser o hipócrita, em sentido pejorativo, como aparece no Novo Testamento significando "o fingidor", "o dissimulado", significava em sentido originário "aquele que responde, que questiona desde baixo", ou seja, desde os mortais, "aquilo que é importante, que merece consideração". O ator, sentido a que Hipocrités passou a ser associado, não é, assim, aquele que finge, que representa, é, em primeiro lugar, aquele que responde desde o lugar de mortal a assuntos que nos interessam decidir, julgar, avaliar e, porque não, pensar.

É bom lembrar que o ator surge no palco quando salta do coro trágico um espaço para o questionamento, para a resposta. É quando surge a possibilidade do diálogo, também, do diálogo entre coro e personagens, entre coro e heróis. O corifeu é o primeiro a se descolar do coro, mas ainda é o seu porta-voz, ainda não é aquele que responde, mas aquele que fala em nome do todo. Aquele que responde recebeu desde a Grécia o nome de Hipocrités, o ator. É ele quem responde e questiona a cena trágica, imersa na relação homem versus todo, cuja hybris sempre presente nos dá provas de nosso erro fundamental por sermos humanos. Assim, o teatro grego, de onde advém o nosso ator, hipócrita, antes de ser um espaço de representação, onde o mundo, trágico, é representado, parece-nos mais um espaço onde o espírito trágico é vivido. Antes de falarmos em representação, a partir da qual há de se considerar dois mundos, o real e o representado, de onde virá o problema da cópia, parece mais sensato falar de um único mundo, vivido e compartilhado por atores e público. Todos reconhecem o trágico, todos reconhecem os mitos, não há, por parte daqueles que vivem o teatro grego, uma real consideração sobre o fato de os mitos estarem bem representados ou em que medida o estão, mas no fato do impacto da cena "representada", na tragicidade compartilhada, catarticamente compartilhada, ou seja, afetivamente compartilhada. Nesse sentido, como um mundo de afetos é um mundo sensível, um mundo preenchido simplesmente pelas sensações, a nosso ver o que importa na arte do ator não é representar, mas causar, afetar. Eis porque o ator habita ainda um mundo sofístico, um mundo só de sensações, assim como pretendera Crátilo ao recusar as investidas filosóficas de Sócrates (Crátilo, 430a-432a). É a filosofia que trará para 
o teatro a questão da representação, um questionamento do seu lugar de ficção. Mas se o teatro é ficcional, se há um duplo sempre presente na relação que se estabelece entre cena e público, ou seja, se todos ali sabem que se trata de teatro, de um local aonde se vai para ver, ainda assim é preciso desconfiar da distância a que o teatro moderno e a modernidade nos legaram a partir, sobretudo, do romantismo. O estatuto duplo do teatro não significa, em sentido originário, tratar a ficção como um lugar seguro, de descompromisso daquele que assiste, já que aquilo, em sentido estrito, "não existe", é obra de autor, etc., etc. A duplicidade teatral mostra a um grego não o que não existe, mas exatamente o contrário, mostra o que existe, só que revivido. Revive Agamêmnon, revive Édipo, revive todos os heróis trágicos, não como efetivamente viveram ou como todos conhecem, mas justamente na diferença de cada "contação", de cada narrativa, "como poderia ter sido". Eis o duplo para os gregos, não o verdadeiro e o falso, mas aquilo que sei e aquilo que não sei, aquilo que me foi contado e a possibilidade de ser contado diferente. Eis um outro sentido de história também, de pertencimento a um povo, a uma tradição. Não se trata de falsidade, trata-se de uma outra compreensão de verdade, apenas. E é por isso que provocavam os efeitos catárticos nas plateias. A emoção não se dá com o falso, mas com aquilo que é, com aquilo que é possível a alguém sentir. Se vemos no teatro, na sua hipocrisia, isto é, no trabalho dos atores, a proximidade com o falso, é porque talvez tenhamos perdido o verdadeiro sentido do verdadeiro. É em busca dessa disputa pelo papel da verdade no seu trabalho que a pedagogia encontra-se lançada, destinada. Hipócrates, o médico, ou Hipocrités, o ator? Eis dois modelos de verdade e, porque não, de método, segundo os quais a pedagogia pode voltar-se.

Hipócrates serve de método à pedagogia desde Platão, ao menos. Podemos desconhecer esse fato, podemos não ter isso em mente quando atuamos em sala, mas veremos que a influência platônica no modo como concebemos o que precisa ser ensinado é determinante. O filósofo dá as seguintes indicações, retiradas do método do médico, para o nosso trabalho:

Inicialmente, decidir se é simples ou múltiplo o objeto que desejamos dominar por meio da arte e ensinar aos outros; de seguida, no caso de ser simples, examinar suas propriedades e o modo de atuar 
naturalmente sobre determinados objetos, ou o inverso: como sofre a influência destes. Vindo a ter muitas formas, começar por enumerá-las e determinar para cada uma o que foi feito antes para a forma única: ver como e em que atua por sua natureza ou por que coisas e em que condições ela pode ser afetada (Fedro, 270d).

O que essa primeira indicação do método hipocrático nos revela é, portanto, nosso procedimento de divisão do conhecimento. Para saber uma coisa, é preciso saber se ela é composta ou não. Por exemplo, para saber gramática é preciso saber morfologia, sintaxe, semântica, etc., e assim procedemos, dividindo o saber para melhor compreendê-lo, para ver que relações possuem uns com os outros, o que influencia o quê, e qual a melhor ordem para podermos ir compreendendo os assuntos. Só isso explica o nosso fato de dividir os conhecimentos em anos e acreditar numa sequência entre eles. Mas não é só isso. Esse método hipocrático serve a Platão como paradigma para julgar todo tipo de conhecimento. É assim que os princípios aqui indicados servem para julgar a retórica no Fedro, por exemplo. Ter como base, portanto, o método da divisão, que Platão chamará de diaíresis, o que aparentemente é apenas um princípio racional, traz consequências sérias para o ensino de outros saberes. Também nós, em nossas salas de aula, parecemos privilegiar os conhecimentos e as disciplinas que podem ser divididos e sequenciados como propõe o método hipocrático. Platão fala explicitamente que "se lhe faltar [ao orador] o menor desses requisitos [hipocráticos] ao ensinar, discursar ou escrever, por mais que presuma falar de acordo com a arte, dos dois [homens] o mais sabido é o que não se deixa convencer" (Fedro, 272b), ou seja, só aquele que conhece as indicações do método hipocrático e o segue é que poderá ser chamado propriamente de especialista, nesse caso, retórico. O método hipocrático serve, assim, como regra, desde onde é possível julgar quem é e quem não é retórico. Lembremos apenas que quem estabelece essa regra não se considera retórico, ao menos não num primeiro sentido, mas filósofo, e que o método é importado da medicina. Cabe, portanto, a pergunta pela legitimidade de tal julgamento.

Mas ainda que ignoremos a questão da sua legitimidade, o fato é que o método hipocrático estabelece um regime de ordenação entre os saberes, uma espécie de governo entre eles. Porém, diferentemente do 
que indica a palavra hipó-crates, a governabilidade aqui não parece vir de baixo, mas de cima. O saber não é ordenado de baixo para cima, mas inversamente. É o tipo de conhecimento que passa pelo método hipocrático que serve de paradigma para os outros conhecimentos. Claro que se trata ainda de uma ordenação vinda de baixo, no sentido de que é discutida e estabelecida desde um plano humano, do diálogo platônico, mas chama a atenção que o tipo de ordenação estabeleça primeiro o que se colocaria em cima, no topo da pirâmide do conhecimento, a filosofia, e depois os outros saberes. É curiosa também a cooptação que Platão empreende sobre a pedagogia, a poesia e a política. Explicitamente no Fedro, Platão, ou melhor, Sócrates, exorta seu interlocutor a dizer a Lísias, seu professor, mas também a Homero e a Sólon, ícones, respectivamente, da poesia e política gregas que,

se se ocuparem com tudo isso, cientes do que seja a verdade e se forem capazes de sair em defesa de seus escritos, quando chamados e se, como oradores, com seus argumentos deixarem o autor dos escritos em posição secundária: um indivíduo nessas condições não deverá ser designado por nenhum dos nomes correntes entre nós, mas apenas com o que se relaciona com o objeto a que ele se dedicou tão desinteressadamente (Fedro, 278c).

Esse objeto de dedicação receberá logo a seguir o nome de filosofia ${ }^{2}$. Portanto, o que Platão quer, com o método hipocrático, é forçar todos os saberes a se aproximar da filosofia, a se tornar filosofia propriamente dita. Tanto a pedagogia quanto a poesia e a retórica estariam destinadas a isso.

Assim, as referências a Hipócrates não são gratuitas. Platão faz referências recorrentes à obra do médico em outros Diálogos, como o Cármides e o Timeu, e à medicina de uma forma geral, como aparece de forma paradigmática no Górgias, em que serve novamente para distinguir os saberes. Também ali a medicina é o que permite colocar a retórica num grau inferior, como adulação, atividade empírica e rotineira em que se encontram também a toilette e a sofística. O argumento platônico é

2 Cf. Fedro, 278d. 
analógico: "a toilette está para a ginástica como a sofística para a legislação, e a cozinha para a medicina como a retórica para a justiça" (Górgias, 465c). Todos os segundos termos encontram-se num patamar superior de conhecimento, sendo mais reais do que os ilusórios e aparentes primeiros. É assim que Platão pode dizer que a cozinha é uma adulação da medicina ao fazer o mesmo que, por exemplo, a toillete faz com a ginástica, ou seja, "uma prática malfazeja e enganadora, vil e indigna de um homem livre, que ilude com aparências, cores, cuidados da pele e do vestuário, a tal ponto, que interessadas em exibir uma beleza artificial, as pessoas descuram a beleza natural, proporcionada pela ginástica" (Górgias, 465b).

Há uma distinção, então, entre artificial (aparente) e natural, que merece uma maior consideração. Platão usa a medicina como paradigma porque é ela quem permite fazer essa distinção entre aparência e essência, entre visível e invisível, em última instância. No tratado $\mathrm{Da}$ arte, parte do corpus hipocrático, diz-se que se deve "opor o que se vê - e mais ainda o que se percebe - e se esgota na totalidade do espetáculo ao que se vê, porém como epifenômeno, como reflexo de um ser profundo que compete à inteligência (gnóme) ver" (PIGEAUD apud FRIAS, 2004, p. 62). Portanto, é a medicina quem permite a Platão lançar mão de sua teoria sobre a distinção "aparência" versus "essência", "ilusão" versus "real". Dito de outro modo, é a medicina a base de toda a filosofia ocidental, pois foi ela quem nos permitiu desconfiar dos fenômenos tais como eles aparecem em nome de uma verdade invisível, em nome de causas invisíveis que formariam os seres, permitindo a nós, humanos, um outro tipo de explicação da realidade. Isso é chave para entendermos como foi possível passar de um mundo estético para um mundo noético, ou seja, de um mundo onde o critério de verdade eram as sensações, base para a física pré-socrática, e também para a sofística, para um mundo onde o critério de verdade é dado pela compreensão racional dos fenômenos. É a medicina clássica que faz essa passagem. Platão fala claramente que

a medicina, quando trata um doente, observa primeiro a sua natureza, sabe a razão do que faz e está em condições de explicar cada uma das suas operações, ao passo que a cozinha, cujo esforço tende unicamente à produção de prazer, caminha para este objetivo divorciada de toda 
a espécie de ciência, sem examinar a natureza e a origem do prazer, de uma forma que se pode classificar de totalmente irracional, sem distinções de qualquer ordem, conservando apenas por uma prática rotineira a memória daquilo que é usual fazer-se, com cuja repetição busca criar o prazer (Górgias, 501a).

Se a cozinha, a culinária, está totalmente "divorciada de toda a espécie de ciência", e ela está diametralmente oposta à medicina, logo é a medicina o paradigma aqui de ciência para Platão. Se a matemática, especialmente a geometria, serve de modelo às teses platônicas, sobretudo sobre o ser, parece-nos ser a medicina o que propicia a Platão as bases para sua filosofia. Sem a medicina não se entenderia a passagem que Platão faz, nem provavelmente sem seus avanços teríamos chegado a aceitar a metafísica platônica por tanto tempo. A medicina é assim a base do projeto filosófico platônico, base do pensamento ocidental, serve como paradigma da própria filosofia ${ }^{3}$. E isso não é de todo absurdo se analisarmos o Cármides, por exemplo, no qual Sócrates é apresentado como um médico ${ }^{4}$, como um discípulo de Zalmóxis, médico de tradição pitagórica, e no qual, antes de iniciar a investigação filosófica sobre o que é a temperança e se ela se encontra presente em Cármides, propõe que se este se dispuser "de acordo com as instruções do estrangeiro [dos médicos trácios com quem aprendera a arte de Zalmóxis], a franquear-me tua alma, para que primeiro eu a submeta ao encantamento do Trácio [da medicina trácia], depois te aplicarei o remédio da cabeça" (Cármides, 157c). Ou seja, a filosofia não deixa de ser aí uma espécie de medicina que, assim como a trácia, aprendida por Sócrates no exército, ensinava que "não é possível tratar do corpo sem cuidar da alma" (Cármides, 156e). A própria dimensão pedagógica da filosofia platônica é também referendada pela medicina quando, no Laques, a educação é definida como "tratamento [therapeían, terapia] da alma" (Laques, 185e). O próprio conceito de ideia [idéa], talvez o principal conceito platônico, "foi originariamente empregado pelos médicos hipocráticos para designar a entidade nosológica responsável por um conjunto determinado de sinais e sintomas" (FRIAS, 2004, p. 79-80).

\footnotetext{
3 Ver a esse respeito Jaeger (2001, p. 519-521) e Frias (2004, p. 80).

4 Cf. Cármides, $155 \mathrm{~b}$ e 156d.
} 
E ainda no Górgias, ao final de seu intento pedagógico de mostrar o erro ateniense de condenar Sócrates, Platão habilmente faz uma espécie de premonição regressiva ao colocar na boca do filósofo as seguintes palavras: "serei julgado como o seria um médico num tribunal de crianças, acusado por um cozinheiro" (Górgias, 522a). Nem um clamor do médico Sócrates: "Tudo isto [de que me acusas] eu fiz, crianças, no interesse de vossa saúde" (Górgias, 522a), serviria a alguma coisa. Vê-se curiosamente, portanto, que nesse diálogo Sócrates não se exime do que lhe é imputado como crime, realmente corrompeu "a juventude, introduzindo a dúvida no seu espírito" (Górgias, 522b), falou "mal das pessoas de mais idade, tecendo sobre elas considerações desagradáveis, em particular ou em público" (Górgias, 522b), mas tudo isso fez em nome da saúde dos seus concidadãos, como um médico que, diante de um mal de seu paciente, a sua doença, precisa dar-lhe um remédio, por vezes, amargo. Se a filosofia platônica é médica e se, portanto, um dos destinos da pedagogia é Hipócrates, parece importante analisar em que medida nosso trabalho é ainda platônico e em que medida pode não o ser. Vale a pena considerar a metodologia empregada por Hipócrates para nos aproximarmos ou nos distanciarmos dela.

No tratado Da arte, Hipócrates faz uma afirmação fundamental:

para todo fato pode-se descobrir um porquê e, na medida em que há um porquê, o espontâneo não tem manifestamente nenhuma realidade [...] Ao contrário, a medicina, na medida em que é da ordem do porquê e da previsão, tem e terá sempre manifestamente uma realidade ${ }^{5}$ (HIPÓCRATES. Da arte, VI, 4, In: FRIAS, 2004, p. 60).

A pedagogia, numa destinação filosófico-hipocrática, portanto, atua no sentido de que existe explicação para todos os fatos e que essa explicação precisa ser buscada. E, além disso, o que nos parece o principal, esse porquê conhecido torna-se causa de explicação de outros fenômenos semelhantes, há um conhecimento previsível nessa destinação da pedagogia. O professor pode não saber o porquê de todos os fatos, mas os porquês que ele conhece dão conta de explicar e prever alguns fenômenos conhecidos.

5 Traduzido por Frias (2004, p. 60). 
Esse modelo explicativo, cujas bases remontam à inseparabilidade do diagnóstico e do prognóstico na medicina hipocrática, parece conter alguns riscos. Em primeiro lugar, que o prognóstico, ou seja, que a previsão do futuro determine uma relação de presente que é a relação pedagógica. $\mathrm{O}$ encontro entre professores e alunos é assim já predeterminado por uma série de indicações de outras experiências semelhantes que aconteceram. Se todo diagnóstico é já também prognóstico, já que no "momento do encontro entre doente e médico, essa divisão [teórica] deixa de existir, pois o raciocínio clínico opera tanto com os dados da observação clínica quanto com a base de doutrinas médicas" (FRIAS, 2004, p. 46), ou seja, se não é possível um encontro "puro", "neutro", sem os conhecimentos prévios e sem uma projeção, por mais sutil, futura, há que, ao menos, questionarse sobre o peso dado a uma coisa ou à outra. Quanto vale a observação clínica e quanto vale a doutrina médica? Ou, para a educação, quanto vale o acontecimento do encontro pedagógico e quanto valem as teorias pedagógicas? Que peso damos a cada coisa? Que freios são importantes para não prevermos o que sequer está indicado? Se em medicina isso é perigoso, pois pode pressupor, mediante um prognóstico errado, remédios equivocados para a doença existente, também em educação podemos formar algo contrário a uma "disposição natural", ou seja, formatar um certo corpo numa direção oposta à sua.

Ainda dentro de uma metodologia hipocrática, é importante observar o papel da descrição no trabalho médico e verificar suas consequências para o nosso trabalho, "pois não é qualquer sinal ou sintoma que deve ser registrado; é necessário que haja uma seleção, um recorte do que é relevante para a história clínica de cada doente" (FRIAS, 2004, p. 61). Ora, impossível não ver nessa seleção, nesse recorte e nessa anotação dos sinais ou sintomas, o trabalho pedagógico de escolha de conteúdos e materiais de acordo com uma certa observação do grupo. Se o recorte pedagógico, em sua maioria, não seleciona o que é "relevante para a história clínica de cada doente", mas do grupo todo, parece que a grande tarefa pedagógica é olhar clinicamente as individualidades e propor, sempre que possível, "remédios" individuais; uma medicina homeopática, em que as individualidades são consideradas, em contraposição à medicação halopática e genérica, que são hegemônicas. Essa sistematização do trabalho de registro e descrição 
das atividades parece ser o grande desafio da pedagogia hipocrática, assim como também o é para a sua medicina, já que é da correção e do aproveitamento desse trabalho que pode resultar a cura ou a enfermidade dos doentes. Assim também o é para a saúde ou enfermidade de nossos alunos. É da acuidade do olho clínico de um professor, ou seja, daquilo que ele julga ser importante de registro, que pode resultar uma boa escolha ou um bom recorte de que tema, que discussões, que atividade trazer para o trabalho pedagógico.

Há, por fim, uma última consideração da medicina hipocrática cujas consequências para o trabalho pedagógico e para as ciências em geral necessita ser pensado. Hipócrates e seus discípulos usavam como recurso terapêutico, isto é, "como meios de diagnóstico, e não com o fim imediato de cura" (FRIAS, 2004, p. 63), a coação da natureza, ou seja, meios de forçar a natureza de um indivíduo a manifestar certos sintomas. Esses meios eram, por exemplo, "certos tipos de alimentos e de bebidas, para a eliminação do pus; caminhadas e corridas, para a eliminação dos suores e observação da respiração" (FRIAS, 2004, p. 62), tudo isso como forma de diagnóstico. Em termos teóricos, Hipócrates diz explicitamente que "a arte encontrou meios de coação pelos quais a natureza violentada sem prejuízo [...] revela àqueles que conhecem as coisas da arte o que é preciso fazer" (HIPÓCRATES, Da arte, XII, 3, In: FRIAS, 2004, p. 62) e esse conhecimento do que fazer é de posse exclusiva do médico, já que "a escolha do meio a ser utilizado para obrigar o corpo a se manifestar obedece a um certo critério que só o médico é capaz de possuir" (FRIAS, 2004, p. 62). Portanto, essa coação da natureza, violenta, mas sem prejuízos é o que revela ao médico o que fazer. Transpondo isso para o ambiente educativo significaria propor a nossos alunos certas atividades com o único fim de poder melhor entender o que se passa com cada um ou com o grupo, como forma, ainda, de diagnóstico. Isso parece indicar de alguma forma uma manipulação, algo a que os retóricos, paradoxalmente, eram sempre associados. O curioso, no entanto, é que essa manipulação já parece existir. As nossas avaliações não deixam de ser esse trabalho de forçar a natureza do aluno a responder de um certo modo, modo este escolhido de acordo com o que o professor entende ser o melhor. E não há

${ }_{6}$ Traduzido por Frias (2004, p. 62). 
que se esquecer, também, que as avaliações sempre cumpriram também um papel de diagnóstico, o de verificarmos como andam os "sintomas" dos alunos, seus conhecimentos e suas falhas.

Por último, há no corpus hipocrático um tratado cujos reflexos estão presentes em Platão e no pensamento ocidental por muitos séculos: a questão do preconceito cultural. No tratado Ares, águas, lugares, Hipócrates executa uma série de teorizações sobre os povos estrangeiros. É um tratado com o objetivo de compreender a influência de fatores ambientais sobre os estados de saúde e doença. Trata-se, porém, de um grande tratado de suposições frente ao outro. Dentre as pérolas hipocráticas podemos encontrar a que diz que "na Ásia, o clima é ameno, não havendo grandes contrastes entre as estações do ano; a natureza é generosa, tal qual os homens, que são belos, de boa estatura e dóceis; todavia a coragem e a impetuosidade não são seus atributos de caráter" (FRIAS, 2004, p. 65)7. Hipócrates está falando da Ásia, mas não seria de se espantar se estivesse falando do Brasil ou da América Latina, como fizeram os conquistadores europeus alguns séculos mais tarde. Por sinal, discursos muito semelhantes. Isso talvez só reforce o quanto o pensamento ocidental se viu e se vê ainda em dificuldade diante da observação do outro, dos seus costumes, de suas crenças e do quanto uma pedagogia hipocrática contribui para isso.

Talvez seja esse precisamente um dos grandes desafios de nosso tempo, repensar essa relação com o outro. A questão que chama a atenção, no entanto, não é que discurso é produzido, mas quais as intenções e implicações de fazer esse discurso do outro, de mostrar o quanto um tipo de cultura, que eu, escritor, desconheço, "condiciona as características físicas e morais de seus habitantes" (FRIAS, 2004, p. 63). Nesse sentido, é interessante ver que desde a base da metafísica ocidental, desde Hipócrates, portanto, essa consideração existe, sendo "um dos pontos culminantes de sua exposição [...] a importância conferida à política como meio capaz de condicionar a ação humana, de infundir coragem em um povo que, por natureza, não estava predisposto a ela" (FRIAS, 2004, p. 65). Se, de alguma forma, não estamos mais propensos a ter essa crença na relação com o outro estrangeiro, parece importante rever essa crença com o outro local, ou seja, em nosso próprio território.

7 Frias comenta essa passagem com base no texto de Hipócrates, Ares, águas, lugares, c. XII, 6, segundo a tradução francesa de Jacques Jouanna. 
Parece também interessante, em educação, repensar até que ponto acreditamos demais nessa influência da política como contraponto a uma natureza mal composta. Até que ponto cremos que é a política, no trabalho pedagógico em cada sala de aula, que resolverá os problemas de um povo que "por natureza" não está propenso a ela. Com isso, obviamente, não estamos fazendo um discurso reacionário, mas apenas questionando até que ponto vai a nossa crença de que a política e a educação transformarão um povo enfermo em um povo sadio. Até que ponto cremos que podemos "infundir coragem em um povo", o nosso, no caso? Ou até que ponto podemos infundir qualquer virtude, qualquer atitude no outro? E como fazemos isso? Não sei se é possível responder a tudo, afinal trata-se de uma crença, mas apesar disso parece importante perguntar, ao menos, para dar conta de que uma destinação hipocrática da pedagogia, metafísica, portanto, por princípio, traz consigo essa consideração sobre o ensino de "civilidade" ao outro.

\section{Hipocrités: o destino-ator}

Poderíamos, quem sabe, passar direto do método hipocrático para o método hipocrítico, ou hipócrita, e considerar essa outra destinação da educação. Mas antes parece salutar mostrar que essa passagem ou escolha não é fortuita, ou seja, não se trata simplesmente de uma aproximação entre duas palavras semelhantes, mas também de uma proximidade própria, cujo caminho, a segunda sofística, em parte, percorre. Vemos em Élio Aristides, um dos primeiros comentadores do diálogo Górgias, um orador latino, a tentativa de refutar justamente o argumento analógico platônico da superioridade da medicina como saber, frente a outros saberes tradicionais, frente a outros tipos de "curas", aproximando novamente ensino e invenção. Diz explicitamente quanto aos saberes, em seu Contra Platão: em defesa da retórica, que "a medicina, que conhece todas as ciências humanas e é superior à arte da cozinha, vale pouco, penso, em comparação com as curas de Delfos que se revelaram aos homens em público e em privado para todas as enfermidades e sofrimentos" (ARISTIDES, 1987, p. 277). Élio Aristides retoma a questão da inspiração como superior ao conhecimento técnico da medicina, algo a que Platão já chamara a atenção, de algum 
modo, no Fedro, com a loucura (manía) divina, mas que não o fazia deixar de lado a metodologia epistemológica que a medicina lhe conferia. Élio Aristides inverte o jogo. Coloca a cura "inspirada" num status acima da medicina, o "não saber" mítico-poético-religioso acima do "não saber" técnico-filosófico. Assim, o não saber, motivo de crítica da retórica e da sua associação com saberes ilusórios como a culinária e a toilette, não é mais razão para o seu descrédito. Pelo contrário, o não saber, do qual as sacerdotisas píticas são seu representante máximo, é um sinal de que se

até um momento desconheciam [as sacerdotisas] até os assuntos de seus vizinhos, de pronto sabem os de todos os homens, pronunciam discursos ante a presença do deus, governam os assuntos públicos e se convertem em guias do que há que se dizer ou fazer em todas as ciências e artes (ARISTIDES, 1987, p. 278-279).

Ou seja, tornam-se o modelo de ação para todas as coisas.

Esse não saber abre, também, a possibilidade de se partir de outros princípios para o ensino, não mais partindo do saber, do qual a medicina representara seu melhor exemplo, mas partindo do não saber. Essa ignorância, que curiosamente deveria ser a base da pedagogia socrática, mas não o é (ao menos não é o mesmo tipo de ignorância), o sofista tardio remonta à sua origem própria que é o discurso religioso, mítico. Nessa "rememoração", no entanto, Élio Aristides permite que a invenção tome o lugar de princípio de ensino, algo valioso para o ensino retórico, mas também artístico e, porque não, religioso. Esse fundo mítico, de onde saem a religião grega, o teatro grego e, também, a retórica grega, é o que pode servir para repensar um outro modelo de destinação da pedagogia. Élio Aristides pergunta a si mesmo "como ensinam as Musas?" (ARISTIDES, 1987, p. 296) e responde que não ensinam abrindo escolas, mas movendo e excitando "a inventiva em nossas mentes" (ARISTIDES, 1987, p. 296). A disposição inicial, portanto, do ensino "pítico", desse ensino "inspirado", é o de mover e excitar as nossas invenções. Ora, mover e excitar algo era justamente o trabalho pedagógico de sofistas e oradores. Mover e excitar a inventividade significa também tirar desse ensino mais "tradicional", em sentido grego, a prerrogativa de um ensino despotencializador, de um 
ensino que retira dos seus alunos sua potência ao deixá-los "reféns" do discurso do professor. O que Élio Aristides reforça é que, ao contrário, o discurso mítico, poético, inspirado, quando ele ensina, esteja ele de posse das Musas, dos poetas, dos oradores e, porque não, também dos filósofos, ensina o aluno a inventar ${ }^{8}$. Num primeiro sentido, ensina o aluno a interpretar, já que é um discurso "cifrado", um discurso que pede interpretação. Um oráculo não diz o que vai acontecer, mas dá indicações, imagens, do que pode acontecer, em um caso ou em outro. Move e excita as mentes a inventarem também no sentido de que os convida a agir, e toda ação é desde o início uma cri-ação. É preciso que eles criem uma resposta, uma ação frente à frase paradoxal da sacerdotisa. É nesse sentido que Hipocrités, o nosso ator grego, pode voltar à cena. É ele quem surge no palco grego como aquele que responde, sentido primeiro de Hipocrités. $\mathrm{O}$ ator "representa", ou melhor, simboliza, o que todos nós, humanos, precisamos fazer frente ao que é misterioso, ao que é desconhecido, mas do qual temos algumas pistas, vislumbramos algumas saídas, alguns caminhos. É ele justamente quem primeiro é movido e excitado em sua mente a inventar, a inventar uma resposta, uma saída. Eis o primeiro aluno das Musas, o Hipocrités, vivenciando a nossa tragédia, aquilo que é trágico em nós. $\mathrm{O}$ ensino, desde essa perspectiva, é então um ensino para a ação, para a resposta, que o mesmo Hipocrités simboliza.

A educação, portanto, nessa destinação hipocrítica, ou hipócrita, contrária, portanto, à metodologia médica, é uma pedagogia da ação e da invenção. Mover e excitar um órgão, no caso, a mente, não deixa de ser também uma ação física, própria de um fisicalismo compartilhado por présocráticos e sofistas. Assim, não é estranho ver que essas duas palavras de uma pedagogia hipócrita apareçam nos tratados de retórica como duas das quatro partes a que um discurso retórico deve submeter-se.

\footnotetext{
8 Certamente, no restante do livro, Élio Aristides nem sempre é consequente com essa capacidade de invenção aqui outorgada ao aluno, toda vez que ela se insere numa visão hierárquica derivada da desigualdade de saberes em um e outro caso. Assim, por exemplo, diz adiante (ARISTIDES, 1987, p. 308) que "é próprio do mando inventar e ordenar, ao que escutar e aprender é próprio do inferior". Ou seja, neste caso pareceria que a invenção é própria apenas de quem sabe. Adentrarmos a elucidação dessa aparente contradição do sofista nos levaria para além dos limites do presente trabalho.
} 
A primeira é a invenção (heurésis, em grego), a busca que empreende o orador de todos os argumentos e de outros meios de persuasão relativos ao tema de seu discurso. A segunda é a disposição (taxis), ou seja, a ordenação desses argumentos, donde resultará a organização interna do discurso, seu plano. A terceira é a elocução (lexis), que não diz respeito à palavra oral, mas a redação escrita do discurso, ao estilo [...] A quarta é a ação (hypocrisis), ou seja, a proferição do discurso, com tudo o que ele pode implicar em termos de efeitos de voz, mímicas e gestos (REBOUL, 2004, p. 43-44).

Todas essas indicações, no entanto, não nos remetem ao hipócrita primevo, ao ator grego, já que são fruto de uma estética nascente, que surge com Aristóteles e, com respeito à retórica, vai derivar em Cícero e Quintiliano, principalmente, como os grandes expoentes de tratados retóricos. Se só podemos aproximar-nos da hipocrisia grega, isto é, do trabalho de respondente de nossos problemas que o ator simboliza, por via indireta e não por meio de sua voz, isso não deixa de ser uma ironia do destino. Nossa hipocrisia, agora não mais em sentido grego, consiste justamente em tratar dos hipócritas, atores, como se a eles tivéssemos acesso. Se essa hipocrisia consiste numa mentira, ou não, isto é, numa história "falsa", ou nem tanto, é algo a ser decidido no limite mesmo de nossa atuação que se inicia agora, ou seja, nos limites mesmos da nossa hipocrisia.

Comecemos, pois, pelo início: Aristóteles. O que significa, então, a ação, essa hypókrisis? O filósofo afirma que

esta ação ocupa-se da voz, das diferentes maneiras de a empregar para expressar cada paixão: ora forte, ora fraca, ora média; estuda igualmente os diferentes tons que a voz pode assumir, alternadamente aguda ou grave ou média, já que se ocupa do ritmo a ser empregado em cada circunstância (ARISTÓTELES, 1403b, p. 34-40).

Portanto, concentrar-nos numa destinação hipócrita para a pedagogia é se concentrar fundamentalmente na voz, de professores e alunos, naquilo que falam uns aos outros e, principalmente, no modo como falam com as suas vozes, nas suas possibilidades de intensidade de ritmo e 
de harmonia, já que "não é sem importância, a fim de focalizar um assunto, exprimir-se de uma maneira ou de outra" (ARISTÓTELES, 1404a, p. 1213). O que vem a ser, portanto, um estudo da voz, dos diferentes tons? É um estudo "objetivo" da voz, isto é, há um modelo de voz e de tons a seguir? Ou é uma busca de uma voz própria? Há realmente uma separação clara entre o próprio e o alheio, entre o original e o imitado quando falamos de voz? É aqui que entram em jogo as noções de ensaio, de improvisação e de repetição. Um ator assume, encontra uma voz mediante esse trabalho de buscar, de brincar, de modular a sua própria voz. Ritmos, harmonias, tudo isso também sobrevém ao ator mediante esse trabalho de ensaio, de repetição. A repetição não é, assim, imitação, mas renovação. Isso também nos ajuda a pensar porque nos parece sem sentido fundar uma pedagogia hipócrita nas descrições de ação dadas nos tratados retóricos. Se elas possuem algum valor e é muito interessante vermos o trabalho exegético de Aristóteles, Cícero e Quintiliano ${ }^{9}$ tentando postular regras e sentidos para diversos movimentos, seja das vozes, seja de uma linguagem gestual que os dois últimos incorporam ${ }^{10}$ para a sua retórica, a partir das performances de atores e oradores, fixarmo-nos somente nessas descrições é atar-se, ainda, ao sentido de ficção que justamente Aristóteles desejara e ao lugar ao qual submetera a retórica e as artes em geral, um lugar de fingimento, de representação, de imitação. E a isso sequer escapam os professores de retórica, sejam atuais, sejam antigos, e temos os exemplos de Cícero e Quintiliano para nos servir de prova ${ }^{11}$. Todo trabalho descritivo

\footnotetext{
9 As citações de Quintiliano são traduções livres da versão inglesa publicada em 19201922 como parte da tradicional coleção Loeb Classical Library, traduzida do latim por H. E. Butler. Tal tradução encontra-se Disponível em: <http://penelope.uchicago.edu/thayer/e/ roman/texts/quintilian/institutio_oratoria/home.html>. Acesso em: 15 fev. 2013.

10 "Já que as palavras nelas mesmas contam muito e que a voz adiciona sua força à matéria falada, enquanto o gesto e o movimento são cheios de significância, nós poderemos estar certos de achar algo como a perfeição quando todas essas qualidades estão combinadas" (QUINTILIAN, Institutio Oratoria, Livro XI, 3, 9).
}

11 A sistematização da retórica em regras parece perder sob os dedos o essencial da contribuição retórica, pois fixa sentidos de vozes, de gestos e movimentos que, se possuem em alguns casos sentidos muito potentes, como a descrição que Quintiliano faz da cabeça e dos olhos (QUINTILIAN, Institutio Oratoria, Livro XI, 3, 66-81), em outros, devido às variações culturais e temporais, já não se pode afirmar o mesmo. Então, para além de uma observância detalhada e fiel das regras retóricas, penso que valha mais a pena buscarmos nos 
desses professores ${ }^{12}$ não atinge o âmago da questão, pois, como afirma o próprio Quintiliano, "apesar do fato de que o sucesso não pode ser atingido sem arte, é inteiramente impossível comunicar o segredo pelas regras da arte" (QUINTILIAN, Institutio Oratoria, Livro XI, 3, 177 - tradução nossa da versão inglesa), ou seja, o ensino propriamente da arte retórica, pelas regras, serve mais como "dicas", como "aspectos a ter em mente" do que efetivamente como técnica. E antes que seja possível ao platonismo retomar, então, sua crítica ao caráter de arte da retórica, o que pode ser o caso, tratando-a como uma espécie de empiria, de saber prático, como a culinária, isso, no entanto, não invalida, por outro lado, que exista um ensino e, de certo modo, uma aprendizagem nesse saber. Assim, ser ou não ser arte não define, como queria Platão, a possibilidade didática de um certo saber. $\mathrm{O}$ sofista e o professor de teatro podem continuar existindo mesmo que a sua arte não seja adquirida simplesmente pelo "conteúdo" do seu saber. Não é, também, como poderia ser uma segunda hipótese, também aludida por Platão, em especial no Mênon, de que é a natureza simplesmente quem capacita ou não essas pessoas. Como exemplifica o próprio Quintiliano, "cada homem deve fazer conhecer suas próprias peculiaridades e deve consultar não só as regras gerais da técnica, mas sua própria natureza assim como uma visão de formação de sua ação" (QUINTILIAN, Institutio Oratoria, Livro XI, 3, 180). É assim que se forma o orador, mas também o ator, já que o exemplo de Quintiliano vem de dois atores cômicos gregos, Demétrio e Estratocles, ambos excelentes, mas diferentes quanto às suas qualidades. Não há, portanto, um único modo de ser um bom ator ou orador, e a cópia simplesmente de um modelo único é talvez o pior efeito desejado, pois "se um desses atores tivesse apropriado qualquer dos truques do outro, teria produzido o mais inapropriado efeito" (QUINTILIAN, Institutio Oratoria, Livro XI, 3, 180). A questão, portanto, da ação teatral, de nossa hipocrisia, não é uma questão de cópia de um modelo único, identitário, e se há um trabalho de repetição no trabalho do ator ele é sem centro.

seus tratados as indicações gerais do que venha a ser a ação retórica e de sua contribuição para um pensamento em educação. Quanto ao trabalho com a voz e com os gestos, só a ação mesma, no momento das práticas e das improvisações, é que garantirá ou não o ganho de sentido.

${ }^{12}$ Cf. Cicero (2005, p. 171-181) e QUINTILIAN (Institutio Oratoria Livro XI, 3, 66-136). 
E aqui vale a pena lembrar Deleuze quando pensa a repetição e adverte que "cada coisa só existe retornando, cópia de uma infinidade de cópias que não deixam subsistir original nem mesmo origem" (DELEUZE, 1988, p. 121). O ator, portanto, em seu trabalho de criação não deve, segundo Quintiliano, copiar o outro, nem mesmo copiar a regra, mas deve submetêlas à sua natureza e à sua forma de atuação. Ora, isso significa tirar do ator o papel de imitador, de representador, pois a representação, ainda que possa multiplicar infinitas figuras e momentos e dotá-los de automovimento, como as diversas máscaras, nem por isso essas máscaras "deixam de ter um único centro, que é o do grande círculo da consciência” (DELEUZE, 1988 , p. 124). Há uma máscara do escravo, uma máscara do senhor, do rei, etc., estereótipo que a consciência faz retornar, torna presente, para que seja possível aos espectadores e dramaturgos julgar uma performance. Aqui se trata de algo diferente, de fazer com que a cada perspectiva, a cada ponto de vista, a cada ator, ou melhor, a cada atuação, "corresponda uma obra autônoma, dotada de um sentido suficiente: o que conta é a divergência das séries, o descentramento dos círculos" (DELEUZE, 1988, p. 124). Uma atuação não é assim referendada por convergir com outras atuações, por ser explicada pelas regras ou modelos dados pelos tratados retóricos ou estéticos, mas pelo sentido suficiente que possua justamente por ser diferente. Se a diferença aparece, de início, sempre divergindo de uma regra, é possível pensar, e Deleuze é um exemplo disso, que, se todos forem diferentes, ainda assim haverá diferença, pois a divergência não precisa de centro, mas de um outro. A cada outro há a divergência e, portanto, a diferença. $\mathrm{O}$ diferente não é mais o estranho, mas a própria "regra". Só assim conseguimos inverter o sentido de cópia ou de simulacro ao qual o Hipocrités estava atado e ao qual o ensino, entendido em termos retóricos também esteve preso, pois agora podemos ver novamente no simulacro "o verdadeiro caráter ou a forma do que é - o ente" (DELEUZE, 1988, p. 121). O teatro, a ficção, não falam mais do não ser, do sentido sem referência, como queria Aristóteles, porque são simulacros, cópias menos reais do real, mas justamente por serem simulacros, simplesmente imagens, sem centro, falam daquilo que é, daquilo que existe, que é ser. E aqui o nosso Hipocrités pode aparecer de verdade, em cena, respondendo, como um simulacro que é, àquilo que também é, ou seja, pode responder 
como imagem àquilo que nos aflige na condição de estarmos embaixo, na condição de mortais. A destinação hipócrita da pedagogia, assim, ao invés de revestir a educação e os professores, sobretudo, de uma áurea de falseamento, de fingimento, o que pode ser uma vertente de um tal destino, pode também revesti-los de "mais" ser, de "mais" verdade, pois, como indicava Quintiliano, a arte retórica torna cada um responsável em conhecer a sua natureza e exercitar-se em uma prática que condiga com ela e com o seu trabalho. Uma sala de aula dotada desse grau de responsabilidade e de autenticidade é capaz de pensar-se como obra, como

um movimento capaz de comover o espírito fora de toda a representação; trata-se de fazer do próprio movimento uma obra, sem interposição; de substituir representações mediatas por signos diretos; de inventar vibrações, rotações, giros, gravitações, danças ou saltos que atinjam diretamente o espírito (DELEUZE, 1988, p. 32).

E assim, quem sabe, fora das amarras hipocráticas, de controle, diagnósticos e prognósticos, a educação possa recriar-se num outro destino, também possível. Mais criativo, talvez. Hipócrates ou Hipocrités? Qual o destino da pedagogia? Alguém poderia perguntar: o que fazer para a pedagogia ter um ou outro destino? Talvez não seja essa, no entanto, a pergunta. Destino traz junto de si a noção de fatalidade, portanto, a que se destina a pedagogia é impossível saber. Visualizamos caminhos, mas continuamos na encruzilhada. Qual caminho seguir, no entanto, não depende, assim como o destino, totalmente de nós.

\section{Referências}

ARISTIDES, E. Discurso I. Madrid: Gredos, 1987. . Discurso II. Madrid: Gredos, 1997a. . Discurso IV. Madrid: Gredos, $1997 \mathrm{~b}$.

ARISTÓTELES. Retórica. v. 8. Tomo I. São Paulo: Martins Fontes, 2012. (Obras Completas de Aristóteles).

CÍCERO. Retórica a Herênio. São Paulo: Hedra, 2005. 
DELEUZE, G. Diferença e repetição. Rio de Janeiro: Graal, 1988.

FRIAS, I. Doença do corpo, doença da alma: medicina e filosofia na Grécia clássica. São Paulo: Loyola, 2004.

JAEGER, W. Paidéia: a formação do homem grego. São Paulo: Martins Fontes, 2001.

PERSEUS DIGITAL LIBRARY. Disponível em: <http://www.perseus. tufts.edu/hopper>. Acesso em: 24 jan. 2013.

PLATÃO. Diálogos: Fedro, Cartas, O primeiro Alcibíades. Belém: EDUFPA, 2007.

. Diálogos: Sofista, Político, Apócrifos duvidosos. Belém: EDUFPA, 1980.

. Górgias. Lisboa: Edições 70, 2006.

QUINTILIAN. Institutio Oratoria. Disponível em: http://penelope. uchicago.edu/thayer/e/roman/texts/quintilian/intitutio_oratoria/home. html. Acesso em: 15 fev. 2013.

REBOUL, O. Introdução à retórica. São Paulo: Martins Fontes, 2004.

Data de registro: $06 / 03 / 2013$ Data de aceite: 22/01/2014 